\title{
Biotechnological Application of Bacterial Alkaline Thermostable Enzymes in Bio-Detergent Industry
}

\author{
R.A. Bayoumi ${ }^{1}$, S.S. Louboudy, N.M. Sidkey ${ }^{*}$ and M.A. \\ Abd-El- Rahman \\ Botany \& Microbiology Dept., Faculty of Science (Boys) and \\ *Botany \& Microbiology Dept., Faculty of Science (Girls), Al- \\ Azhar Univ., Cairo, Egypt.
}

\begin{abstract}
THIS is an investigation concerned on the production of alkaline thermostable microbial enzymes for application in biodetergent technology. Bacillus licheniformis- B42 and Geobacillus stearothermophilusB78 were selected and identified among one hundred and fifty-three thermophilic bacterial isolates with respect to their ability to produce $\alpha$ amylases, cellulases, proteases and lipases grown on some agro-industrial wastes at $55^{\circ} \mathrm{C}$ and at $\mathrm{pH} 9$ for application in biodetergent technology. Productivity of four alkaline thermostable enzymes by both selected strains using slaughter house wastes (SHW) as best substrate for proteases and lipases and potato peel(PP) as best substrate for $\alpha$-amylases and cellulases. The enzymatic level more affected by incubation temperature, $\mathrm{pH}$, SHW and PP concentrations, inoculum size, incubation period, carbon, nitrogen, metal inducer and vitamins sources, under shaking conditions. Four alkaline thermostable enzymes were produced under all optimal nutritional and environmental conditions and purification by column chromatography on Sephadex G200 and G100, respectively were performed. Purification of four produced alkaline thermostable enzymes steps resulted in raising the purification fold to 17.04,15.24,411.9 and 27.33 times in comparable with crude enzymes for $\alpha$-amylase, cellulase, protease and lipase, respectively. The wash performing analysis of the four enzymes revealed that, it could effectively remove a variety of stains such as blood, apple, chocolate, mango, strawberry, salad and pomegranate by treatment at $55^{\circ} \mathrm{C}$ for 15 min when alkaliphilic-thermostable crude/purified enzymes were added separately or in combination with or without detergent (Rabso) as an Egyptian local detergent product. The crude enzymes of these two bacterial strains proved to be potentially candidates for the application in the detergent technology.
\end{abstract}

Keywords: Microbial enzymes, Alkaline thermostable enzymes, Geobacillus, Biotechnological application, Biodetergent.

The largest application of industrial enzymes is as additives in detergents (Kawada, 1998). Many detergent brands contain combination of protease, lipase, cellulases and other degrading enzymes. Generally proteases and lipases are added to detergent to

\footnotetext{
${ }^{1}$ Corresponding author: Dr. Reda Ahmed Bayoumi; Tel.: +(0020) 24108598;

Fax:+(0020) 22629356.Mobile: (0020) 0103597140,

E-mail address: redaelbayoumi@yahoo.com
} 
digest proteins and lipids from human sweat, foods and soils in cloth fibers. These detergent enzymes (serine proteases) were produced by the fermentation of $B$. licheniformis, B. amyloliquefaciens and/or Bacillus sp. Lipases facilitate the removal of fatty stains such as lipsticks, frying fasts, butter, salad oil, sauces and stains on collars and cuffs (Priest, 2000). Cellulases remove microfibrils and amorphous celluloses, which trap dirt particles and cause a loss of surface smoothness. Treatment with cellulase enzymes removes the small fibers without apparently damaging the major fibers and restore the fabric to its "as new" condition by improving the colour brightness, enhancing the softness and removing particulate soiling. Amylases remove the residues of starchy foods (Beguin \& Aubert, 2000). A combination of amylases, protease and lipase is an important component of detergents for automatic dishwashing machines. Currently, the detergent industry occupies about $25-30 \%$ of the entire industrial enzymes market. Amylases constitute 25\% of the enzyme market (Burhan et al., 2003; Konsula \& Liakopoulou-Kyriakides, 2004 and 2006). A growing new area of application of $\alpha$-amylases is in the fields of laundry and dishwashing detergents (Rodriguez et al., 2006). Detergents with $\alpha$-amylases optimally working at moderate temperatures and alkaline $\mathrm{pH}$ can help to solve this problem (Van der Marrel et al., 2002). B. licheniformis and B.amyloliquefaciens amylases (currently used in detergent) are only partially active under these conditions. Engineering or characterizing new amylases that are optimally active at high $\mathrm{pH}$ should make amylases' use in detergent more efficient. Application of thermostable cellulases that are produced by thermophilic microorganisms appear to be ideal in the enhancement of the efficiency of laundry detergents (Jang \& Chen, 2003; Grgorivski De-Lima, 2005; Ekperigin, 2007 and Gusakov et al., 2007). Cellulases are increasingly used in household washing powders, since they enhance the detergent performance and allow the removal of small, fuzzy fibrils from fabric surfaces and improve the appearance and colour brightness (Bhat, 2000). One of the important parameters for selection of detergent proteases is the $\mathrm{pH}$ value. It is known that detergent proteases perform best when the $\mathrm{pH}$ value of the detergent solution in which it works is approximately the same as the $\mathrm{pH}$ value for the enzyme. However, there are many more parameters involved in the selection of a good detergent protease such as compatibility with detergent components, e.g. surfactants, perfumes and bleaches (Venugopal \& Saramma, 2006), good activity at relevant washing $\mathrm{pH}$ and temperature (Oberoi et al., 2001), compatibility with the ionic strength of the detergent solution, stain degradation and removal potential, stability and shelf life (Showell, 1999). There is always a need for newer enzymes with novel properties that can further enhance the wash performance of currently used enzyme-based detergents. Conventionally, detergents have been used at elevated washing temperatures, but at present there is considerable interest in the identification of alkaline proteases which are effective over a wide temperature range (Oberoi et al., 2001). Detergent lipases are especially selected to meet the following requirements: (1) A low substrate specificity, i.e, an ability to hydrolyzes fats of various composition; (2) Ability to withstand relatively harsh washing conditions $(\mathrm{pH} 10-11$, $30-60^{\circ} \mathrm{C}$ ); Ability to withstand damaging surfactants and enzymes [e.g, linear alkyl benzene sulfonates (LAS) and proteases], which are important ingredients of many detergents formulations (Sharma et al., 2001). Lipases with the desired properties are obtained through a combination of continuous screening (Cardenas et al., 2001) and

Egypt. J. Microbiol. 44 (2009) 
proteins engineering (Kazlauskas \& Bornscheuer, 1998) This study aims to application of the four bacterial alkaline thermostable enzymes in biodetergent industry as safe technology.

Wastes

\section{Materials and Methods}

Slaughter houses (SH) wastes

The slaughter houses wastes applied in this study were collected from different slaughter houses ( $\mathrm{SH}$ ) of El-Hawamdia, Giza, Egypt. The SHW were composed of small intestine, large intestine, some particles from stomach and blood forms. The samples were mixed together, kept at $0^{\circ} \mathrm{C}$ in a refrigerator and then added to the production media.

Potato peels wastes (PPW)

The potato peels wastes were collected from different restaurants in ElHawamdia, Giza, Egypt. These wastes were washed for clay removal, dried in open air and then grounded for application in the production media.

\section{Production media}

The basal medium (BM) was prepared according to Vincent (1970). It contained the following (g/l): Sucrose, $10 ; \mathrm{KNO}_{3}, 0.6 ; \mathrm{KH}_{2} \mathrm{PO}_{4}, 1 ; \mathrm{MgSO}_{4}, 0.25$ and $\mathrm{CaCl}_{2}, 0.1$ per liter. This medium was found most convenient for the production of different enzymes. It was modified to include the following constituents :(g/l) NaCl, 6; $\left(\mathrm{NH}_{4}\right)_{2} \mathrm{SO}_{4}, 1$; yeast extract, 1; $\mathrm{KH}_{2} \mathrm{PO}_{4}, 0.5$; $\mathrm{MgSO}_{4} \cdot 7 \mathrm{H}_{2} \mathrm{O}, 0.1 ; \mathrm{CaCl}_{2}, 0.1$ and distilled water up to one liter.

Potato peels basal medium (PPBM)

It contained the same constituents of BM supplemented with potato peels $(5 \%, w / v)$. After incubation period $10 \mathrm{ml}$ of distilled water was added for amylases and cellulases extraction.

Slaughter house basal medium (SHBM)

It contained the same constituents of BM plus slaughter houses wastes $(5 \% \mathrm{w} / \mathrm{v})$.

Identification of the most potent thermophilic bacterial isolates

The two most potent bacterial isolates (B-42 and B-78) were identified as Bacillus licheniformis and Geobacillus stearothermophilus by examination of their morphological, physiological and biochemical characteristics according to Schallmey et al. (2004), Collee et al. (1996) and Hensyl (1994).

Purification of four hydrolytic thermostable microbial enzymes

The following steps were performed during the course of production and purification of amylases and cellulases produced from potato peels wastes and proteases and lipases produced from SHW.

Amylases and cellulases production by G. stearothermophilus strain -B78

G.stearothermophilus-B78 was allowed to grow optimally under the natural static substrate- solid state fermentation conditions on potato peels for amylases and

Egypt. J. Microbiol. 44 (2009) 
cellulases production. In case of amylase production $1 \mathrm{~g}$ of potato peels per flask of $1000 \mathrm{ml}$ capacity was used and supplemented with $10 \mathrm{ml}$ of the production medium, which contained of (g/l, w/v): $\mathrm{NaCl}, 6 ; \mathrm{K}_{2} \mathrm{HPO}_{4}, 0.5 ; \mathrm{MgSO} .7 \mathrm{H}_{2} \mathrm{O}, 0.1$; $\mathrm{CaCl}_{2}, 0.1$; yeast extract, 1 ; in addition to ammonium molybolate and L-histidine, $\mathrm{pH}$ was adjusted at 9 , and inoculated with $2.5 \mathrm{ml}$ of bacterial suspension, incubated for $72 \mathrm{hr}$ at $55^{\circ} \mathrm{C}$. While in case of cellulase production, $1.5 \mathrm{~g}$ of potato peels per flask of $500 \mathrm{ml}$ capacity was used and supplemented with $10 \mathrm{ml}$ of the production medium, which contained (g/l, w/v): $\mathrm{NaCl}, 6 ; \mathrm{KH}_{2} \mathrm{PO}_{4}, 0.5 ; \mathrm{MgSO}_{4} .7 \mathrm{H}_{2} \mathrm{O}, 0.1$; $\mathrm{CaCl}_{2}, 0.1$; yeast extract, 1 in addition to starch, DL-aspartic acid and ammonium sulphate, $\mathrm{pH}$ was adjusted at 9, inoculated with $2 \mathrm{ml}$ bacterial suspension per flask and incubated at $55^{\circ} \mathrm{C}$ for $72 \mathrm{hr}$.

Proteases and lipases production by B. licheniformis strain B-42

Strain B-42 was allowed to grow optimally under the optimal semi solid fermentation conditions on slaughter house wastes for proteases and lipases production. In case of proteases production, $1.5 \mathrm{~g}$ of slaughter houses wastes per flask of $1000 \mathrm{ml}$ capacity was used and supplemented with $20 \mathrm{ml}$ of production medium contained the following ingredients(g/l, w/v): $\mathrm{NaCl}, 6 ; \mathrm{KH}_{2} \mathrm{PO}_{4}, 0.5$; $\mathrm{MgSO}_{4} .7 \mathrm{H}_{2} \mathrm{O}, 0.1 ; \mathrm{CaCl}_{2}, 0.1$; yeast extract, 1 in addition to Galactose, ammonium dihydrogen phosphate, EDTA (500ppm), thiamine and arginine, $\mathrm{pH}$ was adjusted at 9 ; inoculated with $0.5 \mathrm{ml}$ of bacterial suspension and incubated at $55^{\circ} \mathrm{C}$ for $72 \mathrm{hr}$. While in case of lipases production, $1.5 \mathrm{~g}$ of slaughter house wastes per flask of $100 \mathrm{ml}$ capacity was used, supplemented with $20 \mathrm{ml}$ of production medium contained (g/l, w/v): $\mathrm{NaCl}, 6 ; \mathrm{KH}_{2} \mathrm{PO}_{4}, 0.5 ; \mathrm{MgSO}_{4} .7 \mathrm{H}_{2} \mathrm{O}$, $0.1 ; \mathrm{CaCl}_{2}, 0.1$; yeast extract, 1.0 in addition to fructose, ammonium sulphate, $\operatorname{EDTA}(25 \mathrm{ppm})$, thiamin, $\mathrm{pH}$ was adjusted at 9 , inoculated with $1.5 \mathrm{ml}$ of bacterial suspension and incubated at $55^{\circ} \mathrm{C}$ for $72 \mathrm{hr}$.

Preparation of cell-free filtrate

At the end of incubation period, $10 \mathrm{ml}$ of distilled water was added to each flask in case of potato peels, while in case of slaughter house wastes no water was added and then the media filtered through a gauze piece to remove solids. The bacterial growth was harvested by centrifugation at $5.000 \mathrm{rpm}$ for $15 \mathrm{~min}$ and then was filtrated, to obtain the cell-free filtrate that was preserved in the refrigerator as a crude enzyme. This step was carried out in case of the four enzymes cell-free filtrate.

\section{Ammonium sulphate fractionation}

The chart of Gomori (1955) as mentioned by Dixon \& Webb (1964) was applied to calculate the solid ammonium sulphate to be added to achieve any given concentration of the cell free filtrate under investigation. At first only $100 \mathrm{ml}$ of the CFF of the crude enzymes under investigation were first brought to $20 \%$ saturation by gradual addition of solid ammonium sulphate and the precipitated protein was obtained by centrifugation for $15 \mathrm{~min}$ at $15.000 \mathrm{rpm}$ under cooling $\left(10^{\circ} \mathrm{C}\right)$. The obtained pellet was dissolved into $5 \mathrm{ml}$ of Tris-buffer $(0.2 \mathrm{M})$ at $\mathrm{pH}$ 9.0 in order to determine the enzyme activity and protein content. Whereas, the remaining supernatant was treated with ammonium sulphate, was added again to the left of supernatant in order to achieve 40,60, 80 and $100 \%$ saturation.

Egypt. J. Microbiol. 44 (2009) 
For each one ammonium sulphate concentration, enzyme activity and protein content were measured, then the specific activity for each fraction was calculated.

\section{Dialysis}

The procedure was performed by introducing the obvious precipitate (Selected ammonium sulphate ppt. in solution after dissolving in Tris- buffer adjusted at $\mathrm{pH}$ 9) into dialysis bag for dialysis against distilled water for $12 \mathrm{hr}$. The obtained enzyme preparation was concentrated against sucrose before the application in column chromatographic technique.

\section{Column chromatography on Sephadex G200 colum}

The dialyzed-partially purified-enzymes preparation was applied onto a column packed with sephadex G 200 and equilibrated with Tris-buffer (0.2M) adjusted at $\mathrm{pH} 9$, then eluted with the same buffer. Preparation of the gel column and the fractionation procedure was carried out as mentioned by (Soliman, 2003).

\section{Application of crude and purified enzymes in detergent trial experiments \\ Wash performance analysis}

Wash performance analysis of enzymes on small square pieces $(7 \mathrm{~cm} \mathrm{X} 7 \mathrm{~cm})$ of a new cotton fabric was performed in the similar way as described by Oberoi et al. (2001). Samples of human blood, chocolate, salad, pomegranate, apple, mango and strawberry were used to stain (spot) the cloth cotton fabric, while unstained cloth piece was used as a control. The stained cloth pieces were subjected to wash treatments at $28^{\circ} \mathrm{C}$ (room temperature) and $55^{\circ} \mathrm{C}$ with tap water, Tris-buffer $(0.2 \mathrm{M}) \mathrm{pH} 9$, local detergent $1 \%(\mathrm{w} / \mathrm{v})$ (Rabso), purified amylase, cellulase, protease, lipase, collective group of four purified enzymes, collective group of four purified enzymes in addition to detergent, crude amylase and cellulase, crude protease and crude lipase, collective group of crude enzymes and collective group of crude enzymes in addition to detergent $1 \%$. This experiment was carried out for each stain (spot) as following: (1) Unstained cloth piece as a control (1);(2) Stained cloth piece as a control (2); (3) Flask contain $100 \mathrm{ml}$ Tris-buffer $(0.2 \mathrm{M})$ at $\mathrm{pH} 9$ and stained cloth without any treatment as a control; (4) Flask contains $100 \mathrm{ml}$ of used Tris-buffer $(0.2 \mathrm{M})$ at $\mathrm{pH} 9$; stained cloth and $+0.7 \mathrm{~g}$ commercial detergent (Rabso) ; (5) Flask contain $100 \mathrm{ml}$ of used Tris-buffer $(0.2 \mathrm{M})$ at $\mathrm{pH} 9$; stained cloth and $0.1 \mathrm{ml}$ of purified amylase solution; (6) Flask contain $100 \mathrm{ml}$ of used Tris-buffer $(0.2 \mathrm{M})$ at $\mathrm{pH}$ 9; stained cloth and $0.1 \mathrm{ml}$ of purified cellulase solution ; (7) Flask contain $100 \mathrm{ml}$ of used Tris-buffer $(0.2 \mathrm{M})$ at $\mathrm{pH} 9$; stained cloth and $0.1 \mathrm{ml}$ of purified protease solution; (8) Flask contain $100 \mathrm{ml}$ of used Tris-buffer $(0.2 \mathrm{M})$ at $\mathrm{pH} 9$; stained cloth and $0.1 \mathrm{ml}$ of purified lipase solution; (9) Flask contain $100 \mathrm{ml}$ of used Tris-buffer $(0.2 \mathrm{M})$ at $\mathrm{pH} 9$; stained cloth and $0.4 \mathrm{ml}$ of collective groups from the purified enzymes ( $0.1 \mathrm{ml}$ from each enzyme) solution without commercial detergent ; (10) Flask contain $100 \mathrm{ml}$ of used Tris-buffer $(0.2 \mathrm{M})$ at $\mathrm{pH} 9$; stained cloth and $0.4 \mathrm{ml}$ of collective groups from the purified enzymes $(0.1 \mathrm{ml}$ from each enzyme) solution with commercial detergent ; (11) Flask contain $100 \mathrm{ml}$ of used Trisbuffer $(0.2 \mathrm{M})$ at $\mathrm{pH} 9$; stained cloth and $0.1 \mathrm{ml}$ of crude enzymes from potato peels wastes ; (12) Flask contain $100 \mathrm{ml}$ of used Tris-buffer $(0.2 \mathrm{M})$ at $\mathrm{pH} 9$; 
stained cloth and $0.1 \mathrm{ml}$ of crude enzymes from slaughter house wastes ; (13) Flask contain $100 \mathrm{ml}$ of used Tris- buffer $(0.2 \mathrm{M})$ at $\mathrm{pH} 9$; stained cloth $+0.2 \mathrm{ml}$ of collective group of crude enzymes from potato peels and slaughter house wastes ; (14) Flask contains $100 \mathrm{ml}$ of used 0.2 M. Tris- buffer (pH 9); stained cloth; $0.2 \mathrm{ml}$ of collective groups from the crude enzymes solution and $0.7 \mathrm{~g}$ commercial detergent (Rabso).

Then all of these stained cloth pieces were incubated at two different temperatures $\left(28 \& 55^{\circ} \mathrm{C}\right.$ ) for $15 \mathrm{~min}$. After incubation period, cloth pieces were taken out, rinsed with water and dried. Visual examination of various pieces showed the effect of enzyme in removal of stains in comparison with commercial detergent (Rabso). Also a colour measurement for each cloth piece was determined in Dyeing and Finishing Unit, Department of Cotton Chemistry and Textile Fibers, Cotton Technology Section, Cotton Research Institute, Agricultural Research Center. Results were measured by Perkin-Elmer double beam spectrophotometer, Model Lambada 35 equipped with integrated sphere. Each sample was scanned with D65 illuminant source in the wavelength range 400-700 nm using the standard white tile as the reference for all colour measurements.

\section{Colour measurements}

Colour measurement was determined by advanced spectroscopy in conjunction with Perkin Elmer UV-Win Lab. Measurement of colour strength (K/S) was automatically calculated from reflectance $(\mathrm{R} \%)$ by using Kubelka Munk equation. $\mathrm{K} / \mathrm{S}=(1-\mathrm{R})^{2} / 2 \mathrm{R}$. From reflectance measurements on an automatic filter spectrophotometer, where $\mathrm{K}$ is the absorption coefficient, $\mathrm{S}$ is the scattering coefficient, and $\mathrm{R}$ is the reflectance of dyed samples at the wavelength of the maximum absorption.

Whiteness \& yellowness index (ASTM, 1993)

ASTM E313-96 Standard practice for calculating Whiteness \&Yellowness Indices from Instrumentally measured colour coordinates by using the CIE- system .

\section{Results}

Application of thermostable enzymes in detergent technology was carried out with or without commercial detergent such as an Egyptian product (Rabso) on different clean cloth samples blotched with different materials such as blood, apple, chocolate, pomegranate, mango, salad and strawberry. The blotched cloth samples treated at $55^{\circ} \mathrm{C}$, then whiteness, yellowness, reflectance, colour strength value $(\mathrm{K} / \mathrm{M})$ for each cloth sample were recorded in comparison with unbleached control sample. Data presented graphically in Fig. 1\&2 which showed that, the application of collective group of crude enzymes and commercial detergent (Rabso) on cloth piece blotched with blood and treated at $55^{\circ} \mathrm{C}$ gave the highest whiteness and reflectance values where it reached up to 59.88 and $60.4 \%$, respectively. Also, treatment with collective group of crude enzymes without detergent gave a good result for blood removal from cloth piece. On the other hand, $\mathrm{K} / \mathrm{M}$ value and yellowness exhibited the lowest values at these treatments.

Egypt. J. Microbiol. 44 (2009) 
Data presented graphically in Fig. $3 \& 4$ showed that, the application of crude enzymes from potato peels wastes on cloth piece blotched with apple and treated at $55^{\circ} \mathrm{C}$ gave the highest whiteness value where it reached up to $46.72 \%$. Also, treatment with collective group of crude enzymes supplemented with detergent (Rabso), collective group of purified enzymes with detergent (Rabso) and pure amylase only gave a good removal of apple blotch which appeared by maximal value of whiteness and reflectance and lower value of yellowness and colour strength value (K/M).

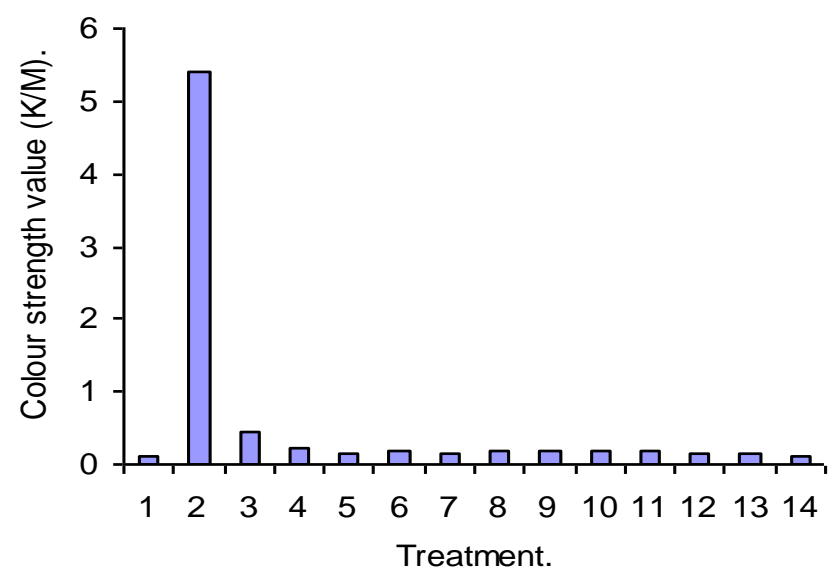

Fig . 1. The colour strength value (K/M) of cloth samples stained with blood treated at $55^{\circ} \mathrm{C}$ with thermostable enzyme(s) and/or commercial detergent(Rabso).



Fig . 2. Whiteness, yellowness and reflectance at their maximum wavelength of clean cloth samples stained with blood treated at $55^{\circ} \mathrm{C}$ with thermostable enzyme(s) and/or commercial detergent(Rabso). 


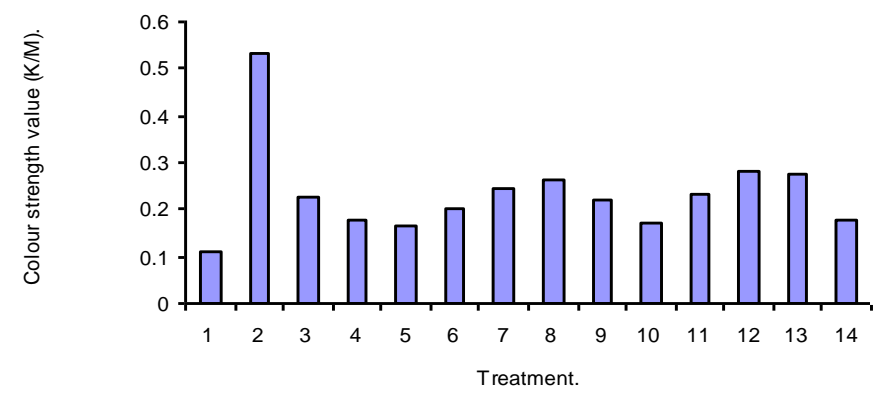

Fig. 3. The colour strength value $(\mathrm{K} / \mathrm{M})$ of clothes samples stained with apple treated at $55^{\circ} \mathrm{C}$ with thermostable enzyme(s) and/or with commercial detergent (Rabso).

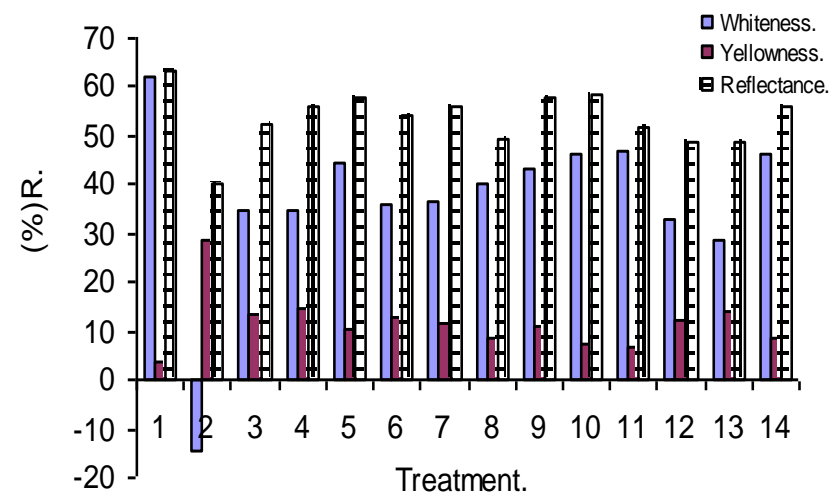

Fig. 4. Whiteness, yellowness, and reflectance at their maximum wavelength of cloth samples stained with apple treated at $55^{\circ} \mathrm{C}$ with thermostable enzyme(s) and/or with commercial detergent (Rabso).

The treatment of chocolate blotched cloth piece at $55^{\circ} \mathrm{C}$ with collective group of thermostable crude enzymes mixed with commercial detergent (Rabso) exhibited a maximal whiteness and reflectance values more than control, where it reached up to 67.6 and $66.1 \%$, respectively. Also, this treatment gave a minimum colour strength value $(\mathrm{K} / \mathrm{M})$. Interestingly, many other treatments not only exhibited a complete removal of chocolate blotches but also remove the non cellulosic materials and impurities of cloth piece such as treatments with collective group of the crude thermostable enzymes without detergent, collective group of the purified enzymes without detergent, pure lipase and detergent only, as shown in Fig. 5\&6.

Egypt. J. Microbiol. 44 (2009) 


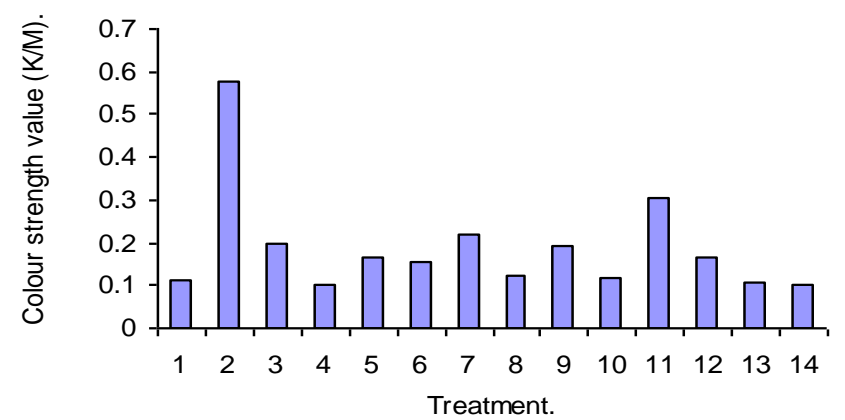

Fig. 5. The colour strength value $(\mathrm{K} / \mathrm{M})$ of cloth samples stained with chocolate treated at $55^{\circ} \mathrm{C}$ with thermostable enzyme(s) and/or with commercial detergent (Rabso).

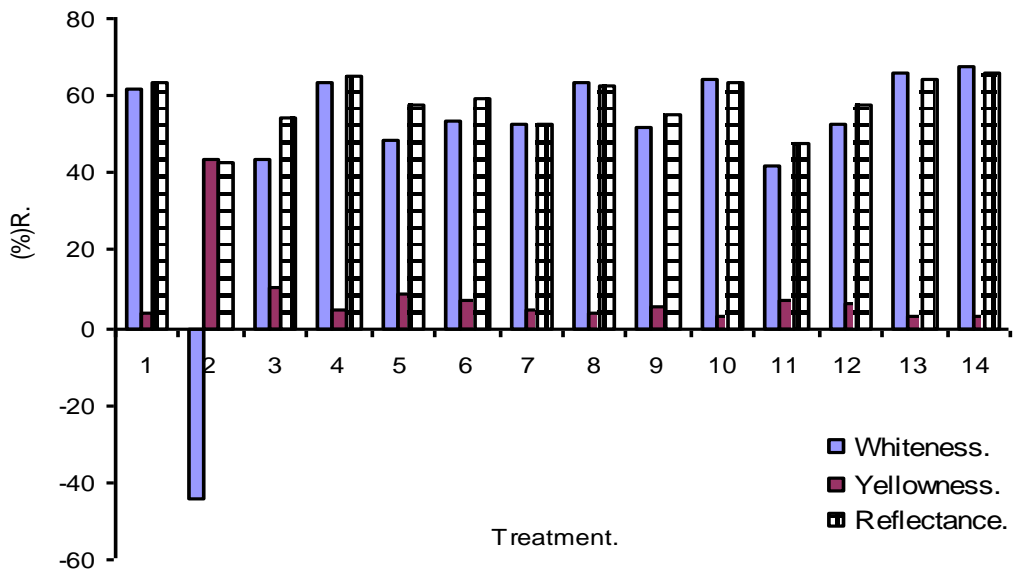

Fig.6. Whiteness, yellowness and reflectance at their maximum wavelength of cloth samples stained with chocolate treated at $55^{\circ} \mathrm{C}$ with thermostable enzyme(s) and/or with commercial detergent (Rabso).

Data recorded presented graphically in Fig. $7 \& 8$ showed that, the purified amylase exhibited the highest whiteness and lowest colour strength $(\mathrm{K} / \mathrm{M})$ value when applied to cloth samples blotched with pomegranate and treated at $55^{\circ} \mathrm{C}$.

Data presented graphically in Fig. $7 \& 8$ showed that, the purified amylase, purified cellulase, purified protease, purified lipase and collective group of the purified enzymes exhibited a good removal of pomegranate blotch by treating at $55^{\circ} \mathrm{C}$, where it exhibited the highest whiteness and reflectance value while lowest colour strength $(\mathrm{K} / \mathrm{M})$ value by application on cloth samples blotched with pomegranate.

Egypt. J. Microbiol. 44 (2009) 


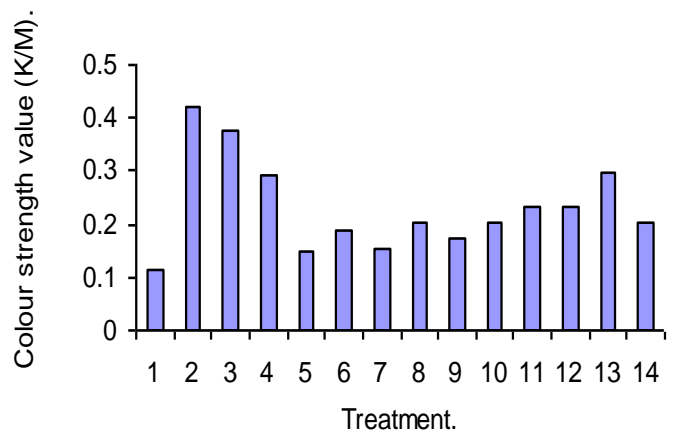

Fig. 7. The colour strength value (K/M) of cloth samples stained with pomegranate treated at $55^{\circ} \mathrm{C}$ with thermostable enzyme(s) with commercial and/or detergent (Rabso).

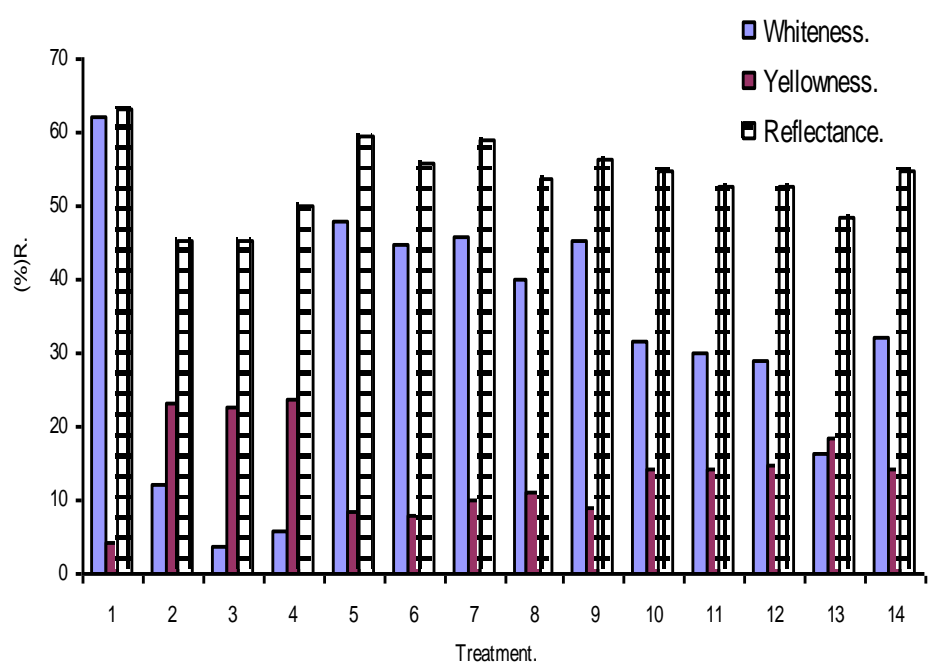

Fig. 8. Whiteness, yellowness and reflectance at their maximum wavelength of cloth samples stained with pomegranate treated at $55^{\circ} \mathrm{C}$ with thermostable enzyme(s) and/or with commercial detergent (Rabso).

Treatment with collective group of the purified thermostable enzymes without detergent gave the highest whiteness and reflectance value by treating the cloth sample blotched with mango at $55^{\circ} \mathrm{C}$. Needless to say that, this treatment not only removed the blotch but also removed any colour and impurities occurred on cloth sample, where the whiteness and reflectance reached up to 62.12 and 62.995, respectively as presented graphically in Fig. 9\&10.

Egypt. J. Microbiol. 44 (2009) 


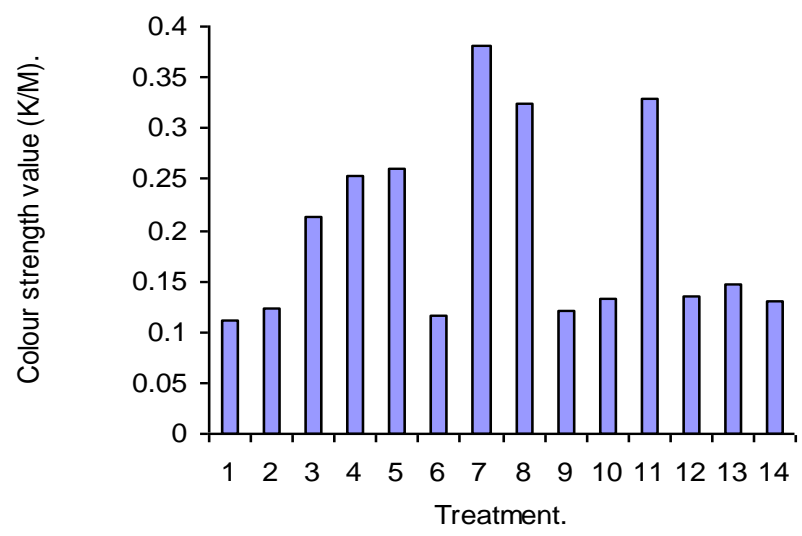

Fig. 9. The colour strength value $(\mathrm{K} / \mathrm{M})$ of cloth samples stained with mango treated at $5^{\circ} \mathrm{C}$ with thermostable enzyme(s) and/or with commercial detergent (Rabso).

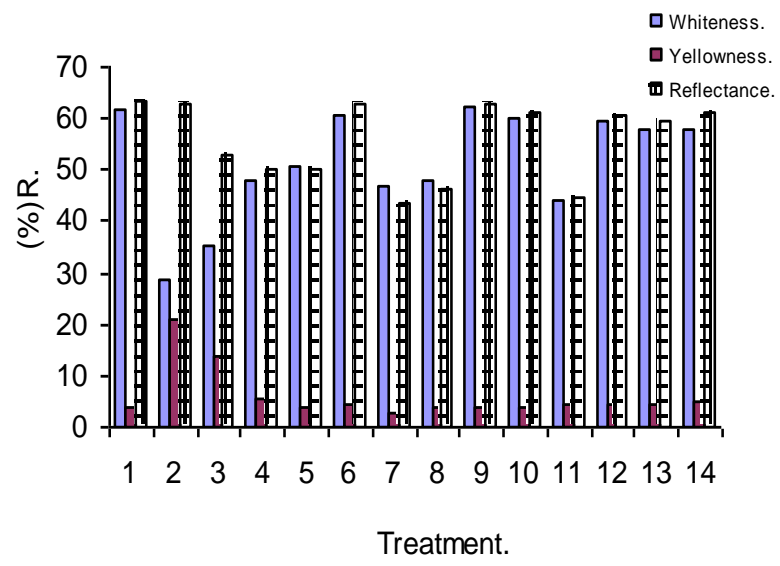

Fig. 10. Whiteness, yellowness and reflectance attheir maximum wavelength of cloth samples stained with mango treated at $55^{\circ} \mathrm{C}$ with thermostable enzyme(s) and/or with commercial detergent (Rabso).

Data presented graphically in Fig. $11 \& 12$ showed that, the cloth piece blotched with salad and treated at $55^{\circ} \mathrm{C}$ recorded its maximum washing performance when treated with collective group of the crude thermostable enzymes. 


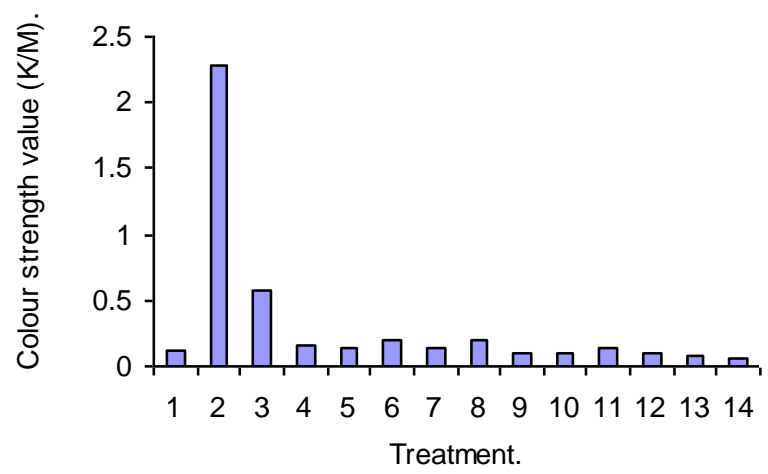

Fig. 11. The colour strength value $(\mathrm{K} / \mathrm{M})$ of cloth samples stained with salad treated at $55^{\circ} \mathrm{C}$ with thermostable enzyme(s) and/or with commercial detergent (Rabso).

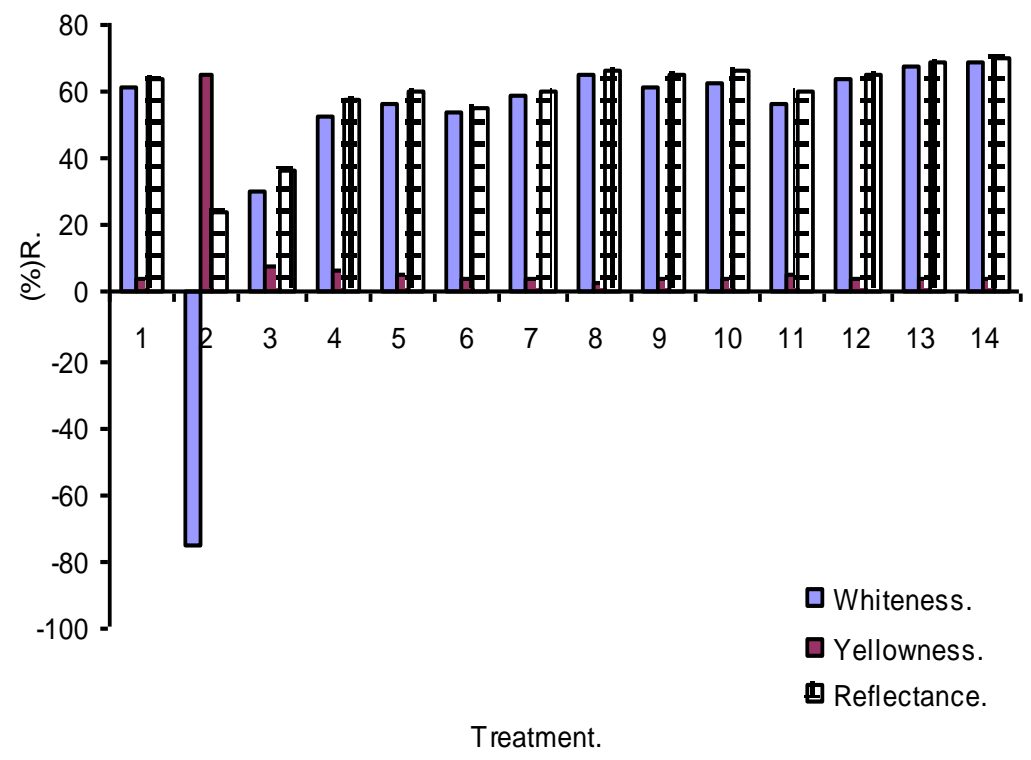

Fig. 12. Whiteness, yellowness and reflectance, at their maximum wavelength of cloth samples stained with salad treated at $55^{\circ} \mathrm{C}$ with thermostable enzyme(s) and/or with commercial detergent(Rabso).

Data presented graphically in Fig. 13\&14 showed that, purified amylase, cellulase, protease and lipase exhibited a good removal of strawberry blotch by treating at $55^{\circ} \mathrm{C}$, where it exhibited the highest whiteness and reflectance values and lowest yellowness and colour strength $(\mathrm{K} / \mathrm{M})$ value of the cloth piece blotched with strawberry. 


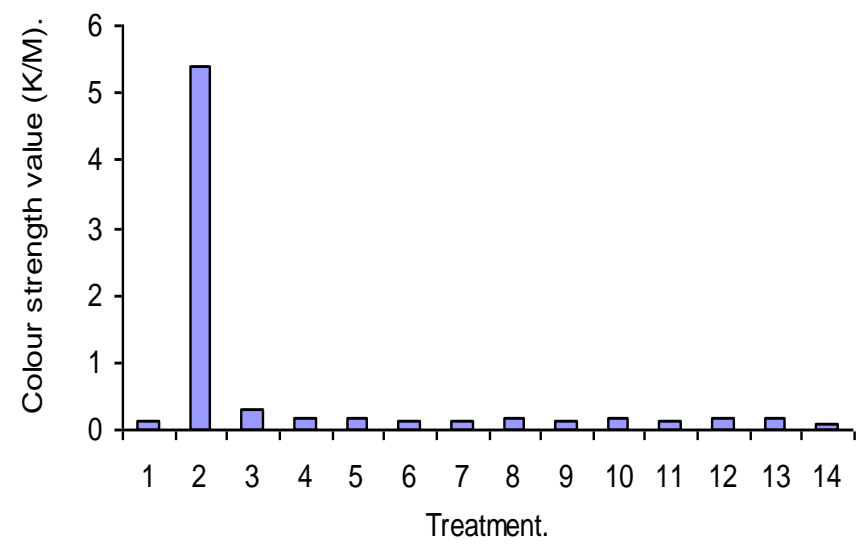

Fig.13. The colour strength value $(\mathrm{K} / \mathrm{M})$ of cloth samples stained with strawberry treated at $55^{\circ} \mathrm{C}$ with thermostable enzyme(s) and/or with commercial detergent (Rabso).

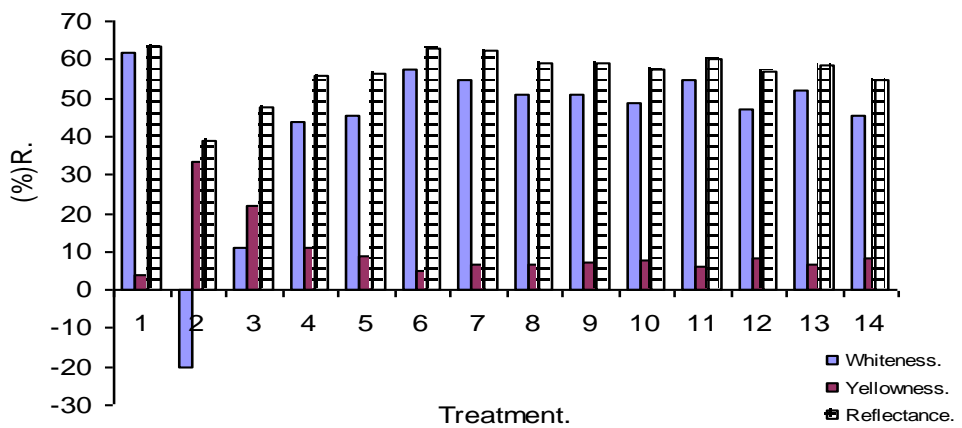

Fig.14. Whiteness, yellowness and reflectance, at their maximum wavelength of cloth samples stained with strawberry treated at $55{ }^{\circ} \mathrm{C}$ with thermostable enzyme(s) and/or with commercial detergent (Rabso).

\section{Discussion}

Limited information are available about the removal of stains by application of the thermostable crude and purified enzymes (separately or in combinations) with or without commercial detergent. The wash performing analysis of the present enzymes revealed that, it could effectively remove a variety of stains such as blood, apple, chocolate, mango, strawberry, salad and pomegranate while treated at $55^{\circ} \mathrm{C}$ for $15 \mathrm{~min}$ by adding thermostable crude/purified enzymes separately or in combination with or without detergent (Rabso) as an Egyptian product. Noteworthy was the effective removal of chocolate stain at $55^{\circ} \mathrm{C}$ by treating with collective group of the thermostable crude enzymes with and without detergent, purified lipase and collective group of purified enzymes with detergent, also removal of mango stain at $55^{\circ} \mathrm{C}$ by treating with collective group of the purified enzymes without detergent and removal of salad stain at $30^{\circ} \mathrm{C}$ by treating with collective group of the thermostable crude enzymes without 
detergent and also removal of salad stain at $55^{\circ} \mathrm{C}$ by treating with collective group of crude enzymes with and without detergent, with the thermostable crude enzymes produced from slaughter house wastes, purified lipase and collective group of the purified enzymes with detergent. The previously mentioned treatments not only resulted in complete removal of stains but also removed the impurities and non cellulosic materials holeded in cloth samples, indicated by whiteness degree, comparing with unbleached control. The best removal of most stains were observed by adding the combination of both thermostable enzymes and detergent to work together. Hence, the supplementation of the enzyme preparations to Rabso detergent could significantly improve the cleaning performance towards many stains. The present enzymes preparations offer applicable value in detergents industries, where it act actively over a broad temperature range. Needless to say, stains can be caused by a variety of substances and appropriate enzymes may not be available, or if available may not be incorporated into detergents or presoak compounds used in launders. But, thus it is not surprising that all stains are not removed by commercial products (Wistreich \& Lechtman, 1984). In the present study, treatments at two temperatures were carried out because the detergent market is very segmented due to widely differing consumer practices which determine the use of detergents and their formulations. For instance, Americans use a short washing cycle, the water is added at $50^{\circ} \mathrm{C}$ and allowed to cool during a $10-15$ min wash at $20-30^{\circ} \mathrm{C}$ (Layman, 1986 and Kalisz, 1988). Even in Europe, the boiling wash $\left(95^{\circ} \mathrm{C}\right)$ is largely a thing of past, but there are a significant national differences. In general, European washing conditions involve warming the water to $40^{\circ} \mathrm{C}$ or $60^{\circ} \mathrm{C}$ in a $30-$ 60 min cycle with or without a cool pre-wash (Winkhaus, 1987 and Kalisz, 1988). In the findings of other investigators, wash performance analysis revealed that, alkaline protease from Bacillus clausii I-52 exhibited high efficiency for the removal of blood, milk and ink stains in the presence of commercial detergent (Joo \& Chang, 2005 and 2006). Also Grebeshova et al. (1999) found that, the addition of alkaline protease to detergents considerably increases (30-40\%) the cleaning effect (particularly in removing stains containing proteins, e.g., blood, cocoa, milk, egg and sauces) and increases the consumption of surface-active substances, thereby improving the ecological situation. Banerjee et al. (1999) found that, thermostable alkaline protease produced by B. brevis improved the cleaning power of various detergents, and remove blood stains completely when used with detergents (Surf Excell ${ }^{\circledR}$ and $\mathrm{Rin}^{\circledR}$ ) in the presence of $\mathrm{Ca}^{+2}$ and glycine. Gerhartz $(1990 \mathrm{a \& b})$ reported that, alkaline proteases were extensively used in laundry detergents for stain removal. Tovey et al. (2001) studied the effect of four laundering agents (water alone, soap, detergent with enzymes and detergent without enzymes) on the removal of allergens at four temperatures $(15,25,45$ and $60^{\circ} \mathrm{C}$ ) and three extraction times $(5,20$ and $60 \mathrm{~min})$ and found that, detergent extracted allergens more than either soap or water alone. Beg \& Gupta (2003) found that, combination of detergent and alkaline protease produced by $B$. mojavensis resulted in complete stain removal and enzyme alone could effectively remove a variety of stains such as blood, grass and beetle. Mahmoud (2004) found that, application of BBW-protease in laundry detergent gave a promising result (using blood and chocolate blotches) compared with commercial detergent (Arial).

Egypt. J. Microbiol. 44 (2009) 


\section{Conclusion}

Results of the present study suggested the potentially value of using $B$. licheniformis B 42 and G. stearothermophilus B78 to produce enzymes by SSF and $\mathrm{SmF}$ using a cheapest substrates for enzyme production. These enzymes were stable over a wide range of $\mathrm{pH}$ and temperature and also showed compatibility with various commercial detergents tested. These enzymes were used as an additive in detergent, to check the contribution of the enzyme in improving the washing performance of the detergent. The supplementation of the enzyme preparation in detergent (Rabso) could significantly improve the cleaning performance towards different stains. Considering the overall properties of different alkaline enzymes of microbial origin and the thermostable alkaline enzymes of the present strains, B. licheniformis B 42 and G. stearothermophilus $\mathrm{B} 78$ are better as regards to $\mathrm{pH}$ and temperature stability, stability in the presence of surfactants, detergents compatibility and above all bleach stability for a potential application not only in heavy-duty detergents for fabrics but also in bleaches and detergents for automatic dishwashing machines.

\section{References}

American Society for Testing and Materials (ASTM) (1993) D:2288 and D:1448 "Calculation of colour differences for instrumentally measured colour co-ordination" and micron air reading.

Banerjee, U., Sani, R., Azmi, W. and Sani, R. (1999) Thermostable alkaline protease from Bacillus brevis and its characterization as a laundry detergent additive. Process Biochem. 35, 213-219.

Beg, Q. and Gupta, R. (2003) Purification and characterization of an oxidation stable, thiol-dependent serine alkaline protease from Bacillus mojavensis. Enzyme and Microbial Technol. 32, 294-304.

Beguin, P. and Aubert, J.P. (2000) Cellulases. In: "Encyclopedia of Microbiology". $2^{\text {nd }}$ edition. Volume 1 A-C. Lederberg, J. (Ed.) pp.744-758. Academic Press.

Bhat, M.K. (2000) Cellulases and related enzymes in biotechnology. Biotechnology Advances, 18, 355-383.

Burhan, A., Nisa, U., Cokhan, C., Omera, C., Ashabil, A. and Osman, G. (2003) Enzymatic properties of a novel thermostable, thermophilic, alkaline and chelator resistant amylase from an alkaliphilic Bacillus sp. Isolate ANT- 6. Process Biochemistry, 38, 1397 - 1403.

Cardenas, J., Alvarez, E., De Castro-Alvarez, M.S., Sanchez-Montero, J.M., Valmaseda, M., Elson, S.W. and Sinisterr, J.V.(2001) Screening and catalytic activity in organic synthesis of novel fungal and yeast lipases. J. Mol. Catal. B: Enzyme. 14, 111-23.

Collee, J.G., Marmion, B.P., Fraser, A.G. and Simmons, A. (1996) "Medical Microbiology" (Mackie and Mac Carteny). 14 ${ }^{\text {th }}$ edition. Churchill Livingstone.

Dixon, M. and Webb, E. (1964) "Enzymes", $2^{\text {nd }}$ edition. Academic Press Inc. New York. 
Ekperigin, M. M. (2007) Preliminary studies of cellulase production by Acinetobacter anitratus and Branhamella sp. African Journal of Biotechnology, 6 (1), 28-33.

Gerhartz, W. (1990a) Genera1 production methods. In: "Enzymes in Industry, Production and Applications". pp.36. VCH Publishers.

Gerhartz, W. (1990b) Industrial uses of enzymes. In : "Enzymes in Industry, Production and Applications". pp. 110-112. VCH Publishers.

Gomori, G. (1955) Preparation of buffers for use in enzyme active studies. In: "Methods in Enzymology". Vol 1. Colwick, S. P. and Kaplan, N. O. (Ed.). Academic Press Inc. Pub. New York.

Grbeshova, R.N., Saldeco-Torres, L.E. and Hidalgo, M.A. (1999) Serine protease of Bacillus subtilis R. Applied Biochemistry and Microbiology, 35, 131-134.

Grgoravski de Lima, A.L., Nasemento, R.P., Bon, E.P. and Coelho, R.R. (2005) Streptomyces drozdowiczii cellulose production using agroindustrial by-products and its potential use in the detergent and textile industries. Enzyme and Microbial Technology, 37, 272-277.

Gusakov, A.V., Salanovich,T. N., Antonov, A. I., Ustinov, B.B., Okunev, O.N., Burlingame, R., Emalfarb, M., Baez, M. and Sinitsyn, A. P. (2007) Design of highly efficient cellulase mixtures for enzymatic hydrolysis of cellulose. Biofuels and Environmental Biotechnology and Bioengineering . 2007 Wiley Periodicals, Inc.

Hensyl, W. R. (Ed.) (1994) "Bergey's Manual of Determinative Bacteriology", $9^{\text {th }}$ edition, Williams \& Wilkins, Baltimore.

Jang, H.O. and Chen, K.S. (2003) Production and characterization of thermostable cellulases from Streptomyces transformant T3-1. World J. Microbiol. Biotechnol. 19, 263-268.

Joo, H.S. and Chang, C.S. (2005) Production of protease from a new alkaliphilic Bacillus sp. 1-312 grown on soybean meal: optimization and some properties. Process Biochemistry, 40, 1263-1270.

Joo, H.S. and Chang, C.S. (2006) Production of oxidant and SDS-stable alkaline protease from an alkaliphilic Bacillus clausii I-52 by submerged fermentation: Feasibility as a laundry additive. Enzyme and Microbial Technology, 38, 176-183.

Kalisz, H.M. (1988) Microbial proteinase (s). In: "Advances in Biochemical Engineering/ Biotechnology", Vol. 36. Fiechter, A. (Ed.). pp. 1-65. Springer, Berlin.

Kawada, T. (Ed.) (1998) Industrial Enzymes Nikkei Biotechnology. Annual Report. Tokyo: Nikkei BP, 1997: pp. 611-626 (in Japanese).

Kazlauskas, R.J. and Bortlscheuer, U.T. (1998) Biotransformations with lipases. In: "Biotechnology". Vol. (8). Rehm, H.; Pihler, G.; Stadler, A. and Kelly, P. (Ed.). pp. 137 192. New York, VCH.

Konsula,Z. and Liakopoulou-Kyriakides, M.(2004) Hydrolysis of starch by the action of an $\alpha$-amylase from Bacillus subtilis. Process Biochemistry, 39, 1745-1749.

Egypt. J. Microbiol. 44 (2009) 
Konsula, Z. and Liakopoulou-Kyriakides, M. (2006) Starch hydrolysis by the action of an entrapped in alginate capsules $\alpha$-amylase from Bacillus subtilis. Process Biochemistry, 41, 343-349.

Layman, P.L. (1986) Industrial enzyme; battling to remain specialties. Chem. Eng. News, 15. $11-14$

Mahmoud, A.I. (2004) Biotechnological recycling of infectious hospital wastes for the sake of safe environment. M.Sc. Thesis. Bot.\& Microbiol.Dept., Fac. of Sci. Al- Azhar University, Cairo, Egypt .

Oberoi, R., Beg, Q., Puri. S., Saxena, R. and Gupta, R. (2001) Characterization and wash performance of an SDS-stable alkaline protease from Bacillus sp. World J. Microbiol. Biotechnol. 17, 493-497.

Priest, F.G. (2000) Enzymes. Extracellular. In: "Encyclopedia of Microbiology". $2^{\text {nd }}$ edition. Volume 2 D-K. Lederberg, J.(Ed.), pp.210-221. Academic Press.

Rodriguez, V. P., Alameda, E.J., Gallegos, J.F., Requena, A.R. and Lopez, A.I. (2006) Thermal deactivation of a commercial $\alpha$-amylase from Bacillus licheniformis used in detergents. Biochemical Engineering Journal, 27, 299-304.

Schallmey, M., Singh, A. and Ward, W.P. (2004) Developments in the use of Bacillus species for industrial production. Can. J. Microbiol. 50, 1-17.

Sharma, R., Chisti, Y. and Banerjee, U.C. (2001) Production, purification, characterization and applications of lipases. Biotechnol. Advances, 19, 627-662.

Showell, M.S. (1999) Enzymes, detergent. In: "Encyclopedia of Bioprocess Technology: Fermentation, Biocatalysis and Bioseparation", Vol 2. Flickinger, M.C.; Drew, S.W. (Ed.). pp. 958-971.Wiley, New York.

Tovey, E.R., Taylor, D.J., Mitakakis, T.Z. and De Lucca S.D. (2001) Effectiveness of laundry washing agents and conditions in the removal of cat and dust mite allergen from bedding dust. Journal of Allergy and Clinical Immunology. 108(3), 369-374.

Van der Maarel, M., van der Veen, B., Uitdehaag, J., Leemhuisa, H. and Dijkhuizen, L. (2002) Properties and applications of starch-converting enzymes of the $\alpha$-amylase family. Journal of Biotechnology, 94, 137-155.

Venugopal, M. and Saramma, A. (2006) Characterization of alkaline protease from Vibrio fluvialis strain VM10 isolated from a mangrove sediment sample and its application as a laundry detergent additive. Process Biochemistry. Accepted in 20 December 2005.

Vincent, J.M. (1970) A manual for the practical study of the root nodule bacteria International Biological Program 7 Marylebone Rood, London. NWi, Blackwell Scientific Publications, Oxford \& Edinburgh. p. 75.

Winkhaus, H.D. (1987) Primary influencing factors and major trends in the European detergent and cleanser market. J. Am. Oil Chem. Soc. 64, 244.

Egypt. J. Microbiol. 44 (2009) 
Wistreich, G.A. and Lechtman, M.D. (1984) "Microbiology". $4^{\text {th }}$ edition. pp. 865-868. Collier Macmillan Publishers, London.

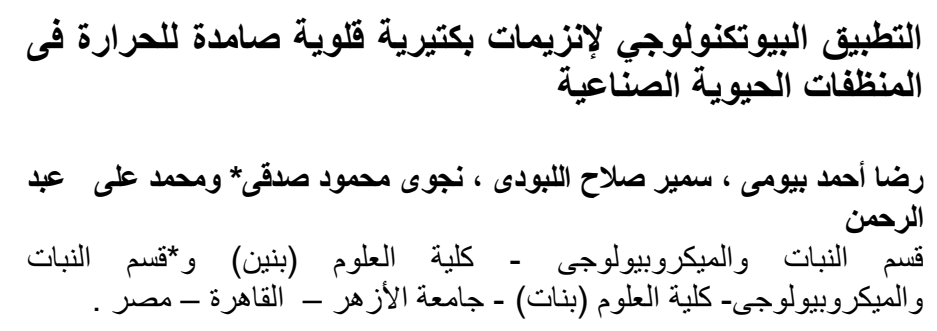



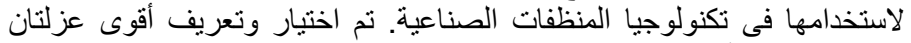

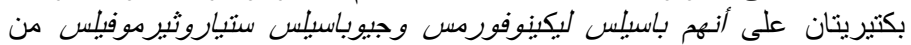

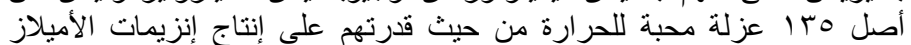

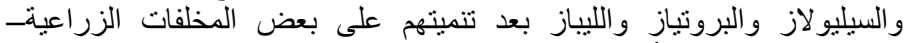

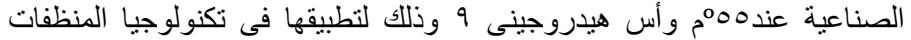
الصناعية. تأثرت إنتاجية الإنزيمات القلاتية الصناتية الصامدة للحرارة الأربعة من السلالتان



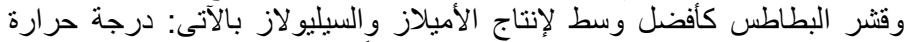

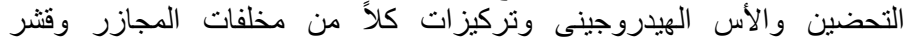

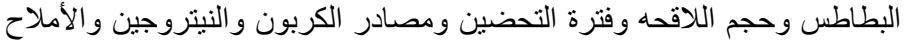



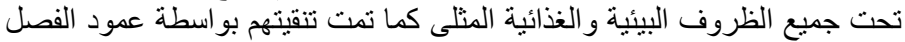



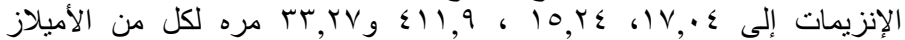

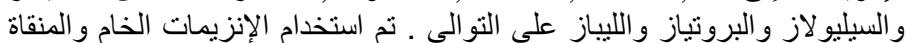



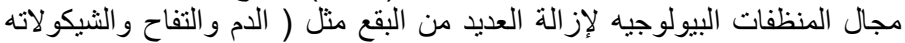

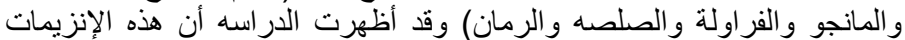

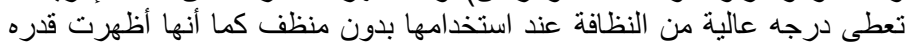

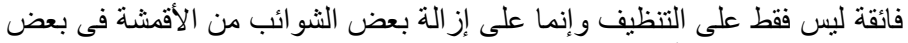

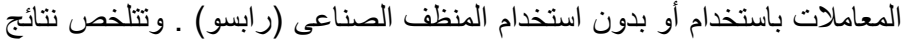

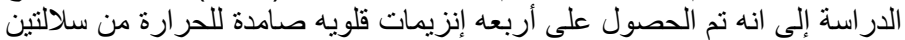

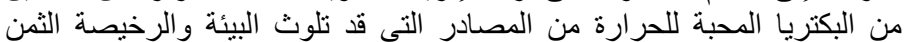
وتطبيقها فى تكنولوجيا المنظفات الصناعية الحيوية و ذلك للحد للحن من استخدام

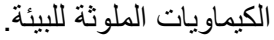

